\title{
HOMOZYGOUS THALASSAEMIA IN AN ENGLISH CHILD
}

\author{
BY \\ JUNE K. LLOYD and G. A. BROWN \\ From the Department of Paediatrics and Child Health, University of Birmingham
}

(RECEIVED FOR PUBLICATION JUNE 25, 1964)

During the past few years there have been several reports of thalassaemia occurring in English families (Garrett and Morton, 1960; Callender, Mallett, and Lehmann, 1961 ; Josse, 1962; Roberts, 1963). All the cases, however, have been of the heterozygous form of the disease (thalassaemia minor and thalassaemia trait). This paper reports the case of an English child with homozygous thalassaemia (thalassaemia major).

\section{Case Report}

The patient, a girl, was referred at the age of 6 years for the investigation of jaundice which had been persistent, though fluctuating in degree, since the age of $3 \frac{1}{2}$ years. Apart from her colour her parents had considered her health to be normal.

On examination she was jaundiced and pale and her spleen was enlarged $1 \frac{1}{2}$ in. $(3 \cdot 8 \mathrm{~cm}$.) below the left costal margin. Her facial appearance (Fig. 1) showed the mongolian features described by Cooley and Lee (1925) in addition to a left internal strabismus. Her height $41.5 \mathrm{in} .(105.4 \mathrm{~cm}$.) and weight $35.5 \mathrm{lb} .(16 \cdot 1 \mathrm{~kg}$.) were both just below the tenth percentile for her age.

Investigations. The haemoglobin was $8.5 \mathrm{~g} . / 100 \mathrm{ml}$, red blood cell count $3.6 \times 10^{6} / \mathrm{c}$.mm., haematocrit $25 \%$, mean corpuscular volume $69.4 \mathrm{c} . \mu$, mean corpuscular haemoglobin concentration $34.2 \%$, mean corpuscular haemoglobin $23.8 \mu \mu g$., and mean corpuscular diameter $8.4 \mu$. The reticulocyte count was $8 \%$, white blood count $3,800 / \mathrm{c} . \mathrm{mm}$. and platelets $180,000 / \mathrm{c} . \mathrm{mm}$. The blood film showed anisocytosis and poikilocytosis of the red cells with many microcytes and some target cells (Fig. 2). The osmotic resistance of the red cells was increased (Fig. 3). The glutathione stability test (Beutler, Robson, and Buttenwieser, 1957) was normal and a direct Coombs' test was negative.

The serum bilirubin was $1.9 \mathrm{mg}$./100 ml., serum albu$\min 4.1 \mathrm{~g}$. $/ 100 \mathrm{ml}$., globulin $3.9 \mathrm{~g}$. $/ 100 \mathrm{ml}$., and haptoglobin very low with a haptoglobin - haemoglobin binding capacity (Rowe, 1961) of less than $0.2 \mathrm{mg}$./ml. of serum. The serum alkaline phosphatase was $10 \mathrm{King}$-Armstrong units. The serum iron was high $(219 \mu \mathrm{g}$./ $100 \mathrm{ml}$.) and the total iron binding capacity of the serum was $263 \mu \mathrm{g}$./100 $\mathrm{ml}$. Serum total lipid was $420 \mathrm{mg}$. $/ 100 \mathrm{ml}$., total cholesterol $125 \mathrm{mg} . / 100 \mathrm{ml}$. , and the lipoproteins separated by electrophoresis (Salt and Wolff, 1957) were normal. Radiographs of the skeleton showed the changes of a chronic haemolytic anaemia.

Foetal haemoglobin estimated by an alkali denaturation technique (Singer, Chernoff, and Singer, 1951) was $87.5 \%$ of the total haemoglobin. Haemoglobin $A_{2}$ determined by paper electrophoresis (Ibbotson and Crompton, 1961) was $4.5 \%$ of the total haemoglobin. No abnormal haemoglobins were detected by electrophoresis on paper and on cellulose acetate in barbitone buffer at $p \mathrm{H} \mathrm{8.6}$ (Fig. 4), or by paper electrophoresis using the modified trishydroxymethylaminomethane buffer of Cradock-Watson, Fenton, and Lehmann (1959) at $p \mathrm{H}$ 8.6 (Fig. 5).

Progress. In the two years since diagnosis there has been little change in the clinical condition. She has not had severe haemolytic crises or required blood transfusions and the haemoglobin has remained in the region of $8.5 \mathrm{~g} . / 100 \mathrm{ml}$. The jaundice has fluctuated with serum bilirubin levels between 2.4 and $4.6 \mathrm{mg}$. $/ 100 \mathrm{ml}$. The spleen has enlarged to $2 \frac{1}{2}$ in. $(6 \cdot 4 \mathrm{~cm}$.) below the left

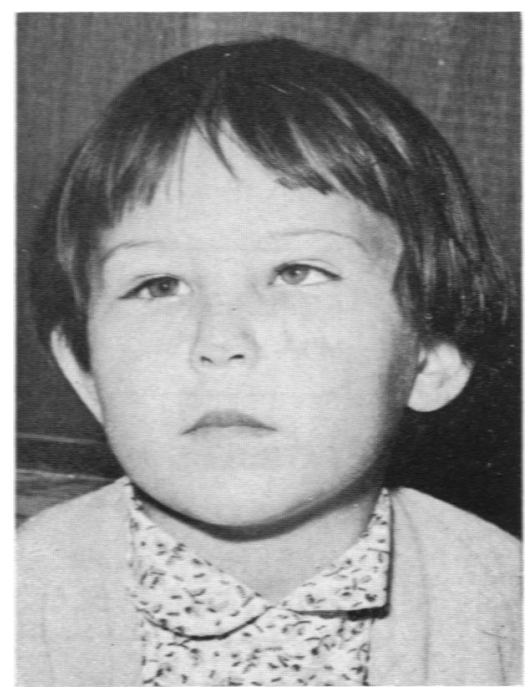

Fig. 1.-The patient. 


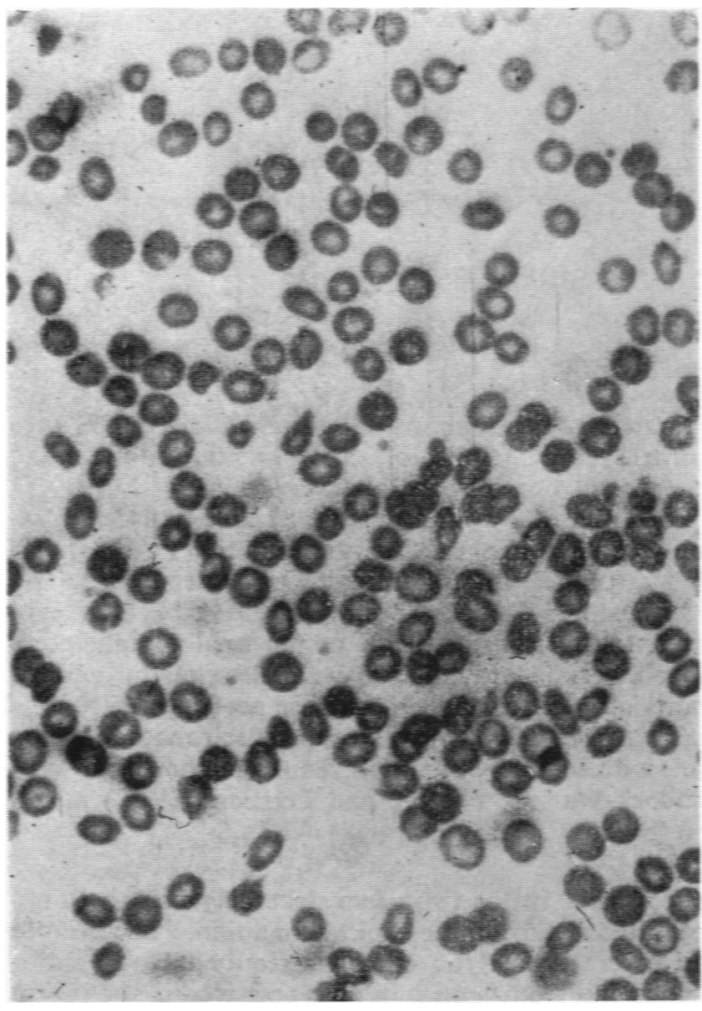

Fig. 2.-The patient's blood film.

costal margin. Her growth has continued at a normal rate.

At the age of 8 years mild folic acid deficiency was demonstrated by the finding of an increased excretion of

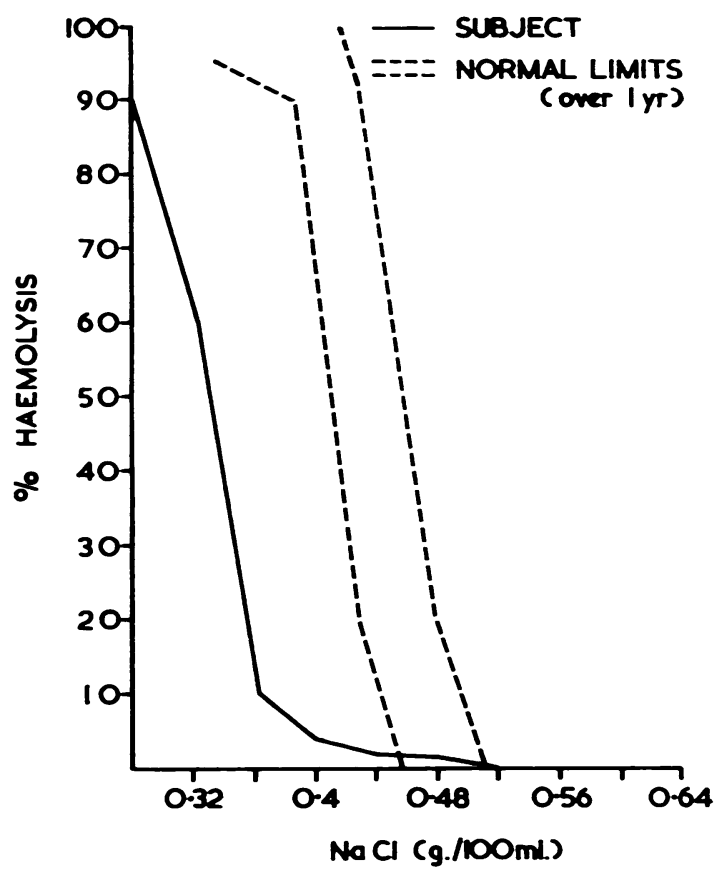

FKG. 3.- Osmotic resistance of patient's red blood cells.

formiminoglutamic acid in the urine after oral histidine (Hayward, 1962), and treatment with folic acid has been started.

Family Study. The parents are related, the paternal grandmother and maternal grandfather having been cousins. Both families have lived in Staffordshire for as

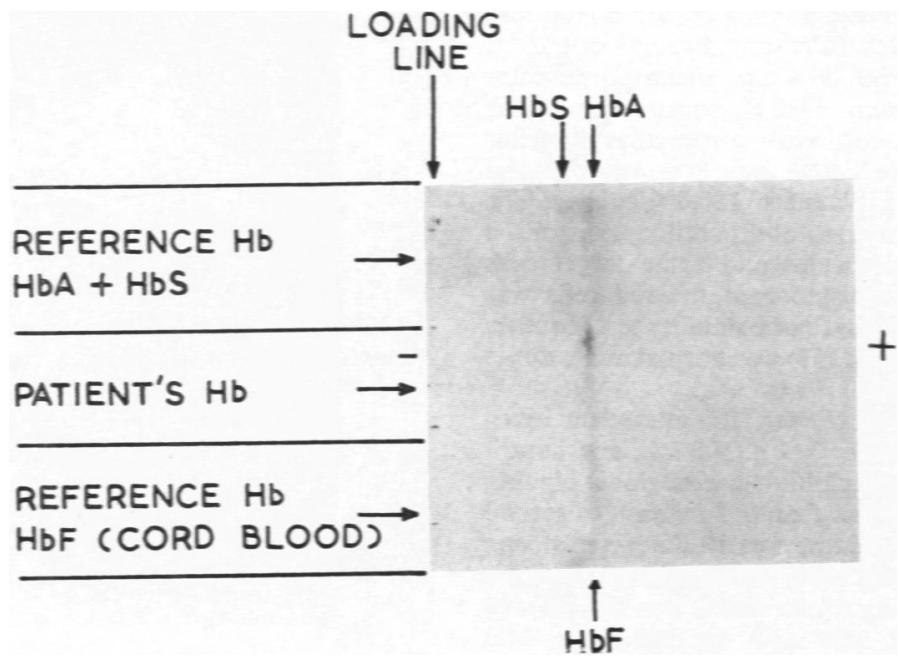

Fr. 4.-Electrophoresis on cellulose acetate, in barbitone buffer at pH 8.6. 


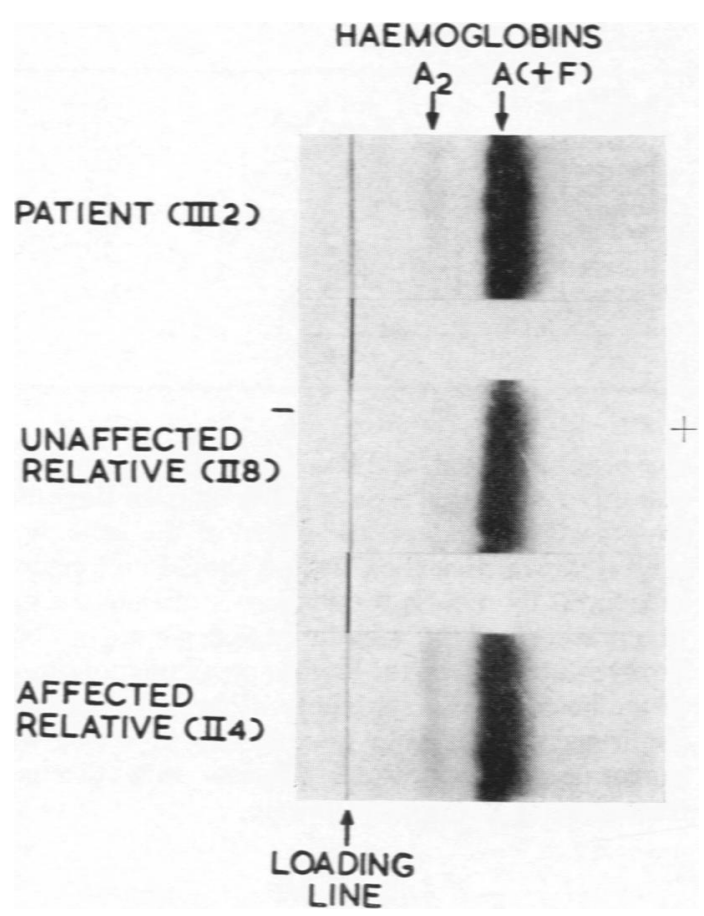

FiG. 5.-Paper electrophoretic separation of haemoglobin $A$ and $A_{2}$ in TRIS buffer at $p \mathrm{H} \mathrm{8 \cdot 6.}$

long as can be remembered and there is no known record of foreign ancestry. Fig. 6 shows the family tree. We were able to examine blood from the only surviving grandparent, both parents, three of the father's five sisters, the mother's brother, and the patient's brother. With the exception of the mother's brother all were found to have heterozygous thalassaemia with anaemia, increased corpuscular resistance, and raised levels of haemoglobin

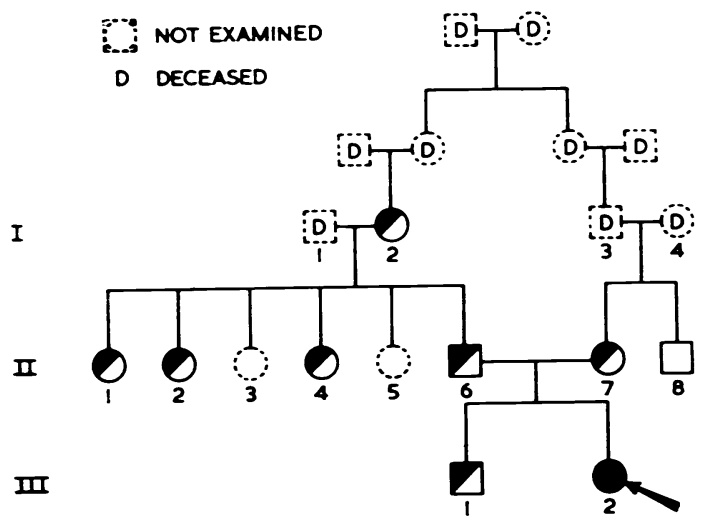

Fig. 6.-Family tree.
$A_{2}$. Increased levels of haemoglobin $F$ were also found in 6 out of the 7 heterozygotes. These results are summarized in the Table. The paternal grandmother has been treated for many years for presumed pernicious anaemia, and, though this diagnosis has not been confirmed, she responded to vitamin B12 injections. One of the father's sisters (II.4) has been diagnosed as having iron deficiency anaemia, and during the past eight years has had prolonged treatment with both oral and intramuscular iron without effect. Both parents were "thought to be anaemic' during childhood and received oral iron. The other affected members of the family are symptomless.

\section{Discussion}

The diagnosis of thalassaemia in our patient was established by the haematological features, the raised levels of haemoglobin $F$ and $A_{2}$, and the family study. The absence of abnormal haemoglobins rules out a combined haemoglobinopathy. The increased levels of haemoglobin $F$ and haemoglobin $A_{2}$ indicate a 3 chain thalassaemia (Ingram and Stretton, 1959). The fact that both parents have thalassaemia and that the patient has a very high level of haemoglobin F strongly supports the diagnosis of homozygous thalassaemia in the patient. The haemoglobin $\mathrm{A}_{\text {? }}$ value of $4.5 \%$ is just above the normal range for the method used (Ibbotson and Crompton, 1961), and though Kunkel, Ceppellini, Müller-Eberhard, and Wolf (1957) reported haemoglobin $A_{2}$ values to be low in the homozygous form of the disease, Fessas (1959) showed that the values were very variable, ranging from subnormal levels to $13 \cdot 3 \%$, with no correlation between the haemoglobin level and the haemoglobin $A_{2}$ content. The affected relatives show the features of heterozygous thalassaemia: anaemia, increased osmotic resistance of the red cells, minimal increases in the amounts of haemoglobin $F$ (with the exception of one paternal aunt, II.2, who had no increase in haemoglobin F), and raised values for the percentage of haemoglobin $A_{2}$. The haemoglobin $A_{2}$ value for the brother is very high but is only just above the upper limit of $15 \%$ quoted as occurring in thalassaemia (Lehmann and Ager, 1960). The values in the other affected subjects agree with those reported in thalassaemic heterozygotes by Ibbotson and Crompton (1961) whose method gives higher results than the starch block method of Kunkel and Wallenius (1955).

The clinical presentation in our patient is of interest, jaundice being the main feature and the anaemia being relatively mild. Dacie (1960) states that overt jaundice is unusual in homozygous thalassaemia. Cooley and Lee (1925), however, noted jaundice in most of their original cases and jaundice has also been described in the heterozygous state (Rietti, 1946; Robinson, Vanier, Desforges, and 
TABLE

RESULTS OF FAMILY INVESTIGATIONS

\begin{tabular}{|c|c|c|c|c|c|c|c|c|}
\hline & & & & & $\begin{array}{l}\text { Total Hb } \\
\text { (g. } / 100 \mathrm{ml} .)\end{array}$ & $\begin{array}{l}\text { Corpuscular } \\
\text { Resistance }\end{array}$ & $(\because$ total Hb) & $(\stackrel{\text { Hb F F }}{\text { total Hb) }}$ \\
\hline $\begin{array}{l}\text { I.2. Gran } 1 . n \\
\text { II.4, Aunt } \\
\text { II.1, Aunt } \\
\text { II.2. Aunt } \\
\text { II.8. Uncle } \\
\text { II.6. Father } \\
\text { II.7. Mother } \\
\text { III.1. Brother }\end{array}$ & $\begin{array}{l}\text { er } \\
\cdots \\
\cdots \\
\cdots \\
\cdots \\
\cdots \\
\cdots\end{array}$ & $\begin{array}{l}\cdots \\
\cdots \\
\cdots \\
\cdots \\
\cdots \\
\cdots \\
\cdots\end{array}$ & $\begin{array}{l}\cdots \\
\cdots \\
\cdots \\
\cdots \\
\cdots \\
\cdots\end{array}$ & $\begin{array}{l}\cdots \\
\cdots \\
\cdot \\
\cdot \\
\cdots \\
\cdots\end{array}$ & $\begin{array}{r}11 \cdot 9 \\
10 \cdot 7 \\
11 \cdot 3 \\
12 \cdot 5 \\
13 \cdot 6 \\
12 \cdot 7 \\
8 \cdot 9 \\
10 \cdot 0\end{array}$ & $\begin{array}{l}\text { Increased } \\
\text { Increased } \\
\text { Increased } \\
\text { Increased } \\
\text { Increased } \\
\text { Increased } \\
\text { Increased }\end{array}$ & $\begin{array}{r}6 \cdot 3 \\
4 \cdot 4 \\
5 \cdot 4 \\
5 \cdot 3 \\
2 \cdot 6 \\
7 \cdot 9 \\
9 \cdot 9 \\
15 \cdot 4\end{array}$ & $\begin{array}{l}2 \cdot 3 \\
3 \cdot 2 \\
2 \cdot 2 \\
0 \cdot 2 \\
0 \cdot 1 \\
2 \cdot 4 \\
6 \cdot 2 \\
4 \cdot 1\end{array}$ \\
\hline Normal range & .. & $\ldots$ & $\ldots$ & . & -- & - & $1 \cdot 3-4 \cdot 3$ & Upto $1 \cdot 7$ \\
\hline
\end{tabular}

Schmid, 1962). It is well recognized that the percentage of haemoglobin $F$ does not correlate with the clinical severity of the disease. Sturgeon, Itano, and Bergren (1955) describe homozygous patients with very high levels of haemoglobin F (82-94\%), who were not severely anaemic. Conversely Zuelzer, Neel, and Robinson (1956) have shown that patients with heterozygous thalassaemia may have severe anaemia.

The importance of considering the diagnosis of thalassaemia in iron refractory anaemia (Garrett and Morton, 1960; Josse, 1962; Roberts, 1963) is confirmed by our study. Three members of the family with heterozygous thalassaemia had previously been treated with iron, and in one of them the treatment was prolonged and included intramuscular administration. Haemosiderosis is reported in both homozygous (Ellis, Schulman, and Smith, 1954) and heterozygous (Étienne-Martin, Klepping, and Binet, 1959) thalassaemia and the possible harmful effects of prolonged iron treatment emphasize the need to make a correct diagnosis. This can only be done with certainty by investigation of the patient's haemoglobin, though the demonstration of increased resistance of the red cells to hypotonic saline is a useful screening test. A family study is necessary to distinguish the homozygous from the heterozygous state.

Folic acid deficiency has been reported in thalassaemia and even in the absence of a megaloblastic blood picture the anaemia may respond to treatment with folic acid (Luhby and Cooperman, 1961). In the absence of definite proof of pernicious anaemia in the patient's grandmother we suggest that the possible vitamin B12 deficiency may have been related to her thalassaemia.

The origin of the thalassaemia gene in the English population is unknown. Commerce and conquest have brought Mediterranean peoples to the British Isles many times over the past two millenia and the gene may have been introduced at a time too remote for recall by family records. Sporadic mutation has also been suggested, and Bannerman (1961) considers that this explanation is more likely than the migration hypothesis. Whatever the origin of the gene, however, it is clear that the clinician should no longer be influenced by race in the diagnosis of thalassaemia. The presence of the gene in English people has been firmly established by the increasing number of reports of the heterozygous state but our finding of the only confirmed homozygote in a family in which consanguinity has occurred suggests that the gene frequency is low in Great Britain.

\section{Summary}

A 6-year-old English child presented with jaundice and was found to have homozygous $\beta$ chain thalassaemia. Eight other members of the family were investigated, and seven, including the parents who are related, have heterozygous thalassaemia. Three of the seven heterozygotes had in the past received iron therapy for their anaemia.

We wish to thank Professor D. V. Hubble for permission to publish this case, Dr. R. D. C. Johnstone for referring the patient, and Dr. F. C. Crittenden and Dr. J. G. Salter for their help with the family study.

\section{RefERENCES}

Bannerman. R. M. (1961). Thalassemia: A Survey of Some Aspects. (Modern Medical Monographs No. 23). p. 20. Grune and Stratton. New York.

Beutler. E.. Robson. M. J.. and Buttenwieser. E. (1957). The glutathione instability of drug-sensitive red cells. J. Lab. clin. Med.. 49. 84.

Callender, S. T., Mallett. B. J., and Lehmann. H. (1961). Thalassaemia in Britain. Brit. J. Haemat., 7. 1.

Cooley. T. B., and Lee. P. (1925). A series of cases of splenomegaly in children. with anemia and peculiar bone changes. Trans. Amer. pediat. Soc.. 37. 29.

Cradock-Watson. J. E.. Fenton. J. C. B., and Lehmann. H. (1959). TRIS buffer for the demonstration of haemoglobin $A_{2}$ by paper electrophoresis. J. clin. Path., 12. 372.

Dacie. J. V. (1960). The Haemolytic Anaemias. 2nd ed.. Part 1. p. 205. Churchill. London.

Ellis, J. T.. Schulman. I., and Smith, C. H. (1954). Generalized siderosis with fibrosis of liver and pancreas in Cooley's (Mediterranean) anemia. with observations on the pathogenesis of the siderosis and fibrosis. Amer. J. Path., 30. 287. 
Étienne-Martin, P., Klepping, Cl., and Binet, J. (1959). Hémochromatose au cours d'une thalassemie mineure. Arch. Mal. Appar. dig.. 48. 844.

Fessas. P. (1959). The Hereditary Anaemias in Greece. In Abnormal Haemoglobins. A Symposium (Council for International Organizations, of Medical Sciences) ed. J. H. P. Jonxis and J. F. Delafresnaye, pp. 260-270. Blackwell Scientific Publications, Oxford.

Garrett. J. V., and Morton. F. (1960). An English family with thalassaemia trait. In Proc. 7th Cong. europ. Soc. Haemat. London 1959; Part II. p. $1058 . \quad$ Karger, Basel.

Hayward. M. A. (1962). The determination of histidine metabolites in the urine of folic acid deficient subjects after oral histidine loading. Proc. Ass. clin. Biochem., 1, 13.

Ibbotson. R. N.. and Crompton, B. A. (1961). Quantitative determination of haemoglobin $A_{2}$ using paper eloctrophoresis. J. clin. Path. 14, 164.

Ingram. V. M.. and Stretton. A. O. W. (1959). Genetic basis of the thalassaemia diseases. Nature (Lond.), 184, 1903.

Josse. S. E. (1962). Thalassaemia minor in an English family. Brit. med. J.. 1. 528.

Kunkel. H. G.. Ceppellini. R.. Müller-Eberhard, U., and Wolf, J. (1957). Observations on the minor basic hemoglobin componen in the blood of normal individuals and patients with thalassemia. J. clin. Invest., 36, 1615.

- and Walkenius, G. (1955). New hemoglobin in normal adult blood. Science, 122, 288.
Lehmann, H., and Ager, J. A. M. (1960). The laboratory detection of abnormal haemoglobins. The Association of Clinical Pathologists, Broadsheet No. 27 (new series).

Luhby. A. L., and Cooperman, J. M. (1961). Folic-acid deficiency in thalassaemia major. Lancet. 2, 490.

Rietti. F. (1946). Hemolytic anemias with increased osmotic resistance of the erythrocytes. Acta med. scand., 125. 451.

Roberts. P. D. (1963). The thalassaemia trait in an English family. J. clin. Path., 16, 593.

Robinson. S., Vanier, T. Desforges. J. F.. and Schmid. R. (1962). Jaundice in thalassaemia minor: A consequence of ineffective erythropoiesis'. New Engl. J. Med.. 267. 523.

Rowe. D. S. (1961). A rapid method for the estimation of serum haptoglobin. J. clin. Path.. 14. 205.

Salt. H. B.. and Wolf. O. H. (1957). The applications of serum lipoprotein electrophoresis in paediatric practice. Arch. Dis. Childh., 32, 404.

Singer, K., Chernoff. A. 1.. and Singer. L. (1951). Studies on abnormal hemoglobins 1. Their demonstration in sickle cell anemia and other hematologic disorders by means of alkali denaturation. Blood. 6, 413.

Sturgeon, P.. Itano, H. A., and Bergren. W. R. (1955). Genetic and biochemical studies of intermediate types of Coolev's anaemia. Brit. J. Haemat., 1, 264.

Zuelzer. W. W., Neel, J. V., and Robinson. A. R. (1956). Abmormal Hemoglobins. In Progr. Haemat.. Vol. 1. ed. L. M. Tocantine. p. 116. Grune and Stratton. New York. 